\title{
Foreign Non-Profit Organizations: Analysis, Comparison, and Experience
}

\author{
Shamsutdinova V. V. \\ Institution of Higher Education \\ University of management "TISBI" \\ Kazan, Russia \\ veronika.post@mail.ru
}

Galeeva V. R.

Department of economics

Kazan national research technical University

Kazan, Russia

galeeva_vr@mail.ru

\author{
Tishkina T. V. \\ Department of Customs \\ Kazan cooperative Institute \\ Russian University of cooperation \\ Kazan, Russia \\ tvt879@mail.ru
}

\author{
Khasanova L. R. \\ Institution of Higher Education \\ University of management "TISBI" \\ Kazan, Russia \\ lileka1971@mail.ru
}

\begin{abstract}
The article deals with foreign non-profit organizations of several countries, their experience and the problems they face. The non-profit sector seeks not only to meet the needs of society, but also to create a stable business climate, a stable economy and a political system based on the principles of democracy and responsibility. The experience of foreign countries shows a variety of institutions and areas for infrastructure support. This is based on national traditions and conditions of socio-economic development of the country, which gives reasons to the allocation of foreign models of support of the infrastructure of Scientific and Production Organizations (SPO). Russia is currently building a non-profit sector and infrastructure, in particular establishing criteria and procedures for monitoring SPO subsidy programs at the Federal level. Work has begun on the identification of criteria and the implementation of a tracking system at the regional level.
\end{abstract}

Keywords-non-profit organizations; individuals; NPOs; foreign experience.

\section{INTRODUCTION}

A non-profit organization (NPO) is an organization whose mission is to support an issue of private or public interest for non-commercial purposes, without the purpose of obtaining monetary profit. NPOs are actively developing in a variety of areas, including art, social interests, charitable foundations, children's education, health, religion, research, sports and more. In most cases, people with excess of wealth turn to philanthropy and create or support such organizations $[11, \mathrm{p}$. 18]. Since those involved in running a non-profit organization must pursue goals that benefit society rather than personal gain, they are not bound by competition from the business sector.

\section{LITERATURE REVIEW}

A non-profit Corporation is a Corporation created by law, government, or judicial authority that is not intended for profit by owners or members. A Corporation whose primary purpose is to make a profit to its owners is not a non-profit Corporation. A non-profit organization is always organized as a non-stock enterprise. A non-profit organization is created for a specific purpose, such as educational, charitable, or related to other socially significant purposes, it may be a foundation, charity, or other type of non-profit Corporation. In some cases, it may be a public Corporation. In many countries, such organizations are exempt from taxes. Most countries have laws regulating the operation and management of NPOs that require compliance with corporate governance rules. Most large organizations should publish their financial statements in the public domain with a detailed description of their income and expenses. In most cases, they are similar to commercial entities, although they often have significant differences. Both non-profit and for-profit organizations should have Board members, steering Committee members, or Trustees who should have a duty of loyalty and trust.

An exception to this rule are churches, which often do not have to make their accounts publicly available, even to their leadership, if the leadership is elected on an elective basis. Foreign experience of NPOs in this aspect is very valuable for non-profit organizations in our country. The opportunity to learn it will certainly benefit Russia's NPO [12, p. 7].

\section{RESEARCH METHODOLOGY}

In the United States, non-profit organizations, as in the vast majority, are created by incorporation into the country in 
which they intend to operate and develop. Non-profit organizations have the right to maintain staff, but many do not exercise this right. An NPO can be a Trust or an Association of organizations. The organization may be controlled by its members, who are elected by the Board of Directors, Board of governors or Board of Trustees. Non-profit organizations have a largely delegate structure that allows groups or corporations to be represented as members. In addition, it has the right to be an organization that is not a Board of Directors.

The main difference between a nonprofit and a for-profit organization is that a nonprofit one does not issue shares or pay dividends (the Commonwealth of Virginia code includes in the nonprofit Corporation laws, which is used to include nonprofits) and does not have the right to pay dividends to its Directors. Moreover, as the for-profit corporations, non-profit organizations have the right to have employees and can pay their Directors reasonably. In many countries, NPOs may be eligible for tax-exempt status, so that the organization itself should be exempt from income tax and other tax burdens, and so that financial sponsors may claim back any income tax paid on donations, or deduct from their own tax base the amount of the donation [7, p.88]. Only some NPOs are exempt from the tax burden, NPOs offer sponsors the benefit of tax deductions on the amount of their donation. If the organization has legal status that exempts it from tax burdens, the organization must specify that its assets must not bring profit to the persons who are its members, Directors, officers or agents [10, p. 56]. In addition, an NPO must have a legitimate charitable purpose in order for the organization to have the purpose of supporting an educational, religious, or charitable mission. These clauses do not mean that the NPO cannot pay employees or contractors salaries or pay for their services that they provide to the organization. This limitation is due to the fact that as long as the organization carries out its activities within its competence, exempt from tax encumbrance purposes, saving funds and uses all the surplus of its income for further functioning, it is not subject to income tax.

\section{RESUlTS}

Financial management is generally divided into three main categories, namely capital structure, capital budget and financial management of short-term assets (also referred to as working capital management). NPIs, however, typically do not generate their own income and depend on external sources to Finance it, making debt with an obligation to pay monthly interest extremely risky and therefore undesirable. In addition, an NCO does not have shareholders and therefore its capital structure does not include a significant capital component and therefore the relevance of the NCO's capital structure theory is limited. Unlike capital structure, capital budget can.".. have a strong impact on the nature of NPIs over the years, as they often involve the commitment of extensive resources over a long period of time." This article, however, seeks to explore the impact of the global financial crisis on the financial viability of NPOs, which is a function of their ability to meet short-term financial obligations. The study focuses on shortterm financial management.

Short-term financial management includes decisions that affect current assets and liabilities, typically related to cash inflows and outflows arising over the next twelve months, and includes cash management, inventory management, and receivables. For most NPIs, inventory management and receivables management issues are likely to be less significant, but forecasting / budgeting future cash requirements and cash management is critical.

Budgeting is considered as one of the most difficult areas of financial management of the organization. One of the main advantages of a budget for an NCO is that, if planned and executed properly, the likelihood of an NCO becoming economically sustainable improves. The incremental approach views existing programmes as only pre-approved taking into account changes in financial resources allocated, which means it takes much less time and also feels less threatening to programme managers.

Given the important role that NGOs play in social development, and in light of the recent global financial crisis, the issue of financial management of NGOs with respect to efficiency and the efficiency with which resources are used is important. For the first time, the law laid the foundations for the management of non-profit organizations and possible forms of their support by state and local authorities. The Federal law "on non-profit organizations", as amended, is currently in force and applies to all non-profit organizations established or being established on the territory of the Russian Federation.

The Canadian customs and tax Agency (CCRA) (formerly the IRS) is the government Department responsible for granting charitable tax status to organizations. The process typically takes from six months to 18 months and requires applicants to meet a number of requirements. One of the main advantages of obtaining charitable status is that the organization can give income to donors for income tax purposes [8, p. 19]. This is a great advantage when you receive donations. In addition, charities receive certain tax benefits. If the organization is based in Canada, and is a nonprofit and charitable organization, it can be considered as a charitable organization within the meaning of the income tax Act. Tax deductions cannot be paid by a non-profit Corporation because it is a non-profit Corporation. It must first apply and be accepted as a charity.

Nonprofits in the United States, like for-profit corporations, are organized and operate primarily under state law rather than under the Federal government. However, there are a number of Federal charities, including the American Red Cross, the Boy Scouts in America, and the U.S. Olympic Committee. Non-profit organizations and individuals who carry out non-profit operations are generally required to comply with the same laws as commercial enterprises. The tax benefits (mentioned above) and some first amendment exemptions are listed below. Directors and officers of nonprofit organizations have a fiduciary duty to non-profit organizations and their beneficiaries, such as the duties of Directors and officers of commercial corporations. Non-profit organizations may be held vicariously liable for injuries inflicted on their third parties by their employees or volunteers, for example, as a result of traffic accidents. For this reason, it is advisable for any non-profit organization to 
obtain liability insurance. Nonprofits that pay workers must comply with minimum wage laws and the requirement for most States to receive insurance coverage for workers. Reliable and nonprofit churches and organizations are special because the first amendment to the U.S. Constitution prevents the government from passing a law establishing religion, and prohibits "free exercise" [6, p.1726]. It connects only to the United States Federal government, but it was extended to States and local governments in the United States by the 14th amendment at the end of the civil war.

Preventing charitable fraud is, before all, the function of the state government and is usually the responsibility of government counsel. There are large differences in laws on charity in different states. In the United States, there is a very strong tradition of non-governmental intervention of organizations in the faith expressed in the paragraph "free exercise" of the first amendment.

Therefore, fraud control (nominal religious organizations operating exclusively in the personal interests of the "Minister") is very weak.

\section{DISCUSSION}

Legal status of non-profit foreign organizations these days have more than formed by non-profit organizations for a calm implementation of their activities.

Activities of NPOs in most countries are regulated by a sufficient number of regulatory acts, depending on the type of NPOs and its activities. Because the level at this stage of development of non-profit organizations is justified by the indicator of development of civil society (degree of citizens ' involvement in social activities, influence on decisions created by power), at this stage development of the society needs constant work to improve the legal system, to develop a more flexible and clear regulatory framework, to develop bureaucratic procedures by the executive branch, related to the work of non-profit organizations.

The organization must not only meet the needs of the state in which it works with nonprofits, but also comply with the complex rules of the IRS. These provisions are used not only to determine whether an organization is exempt from taxes in the course of its activities as a non-profit organization. If the purpose of the organization is one of the purposes specified in $\S 501$ (c) (3) of the Tax code, it may apply that the taxable donations are intended for individuals or entities to make them. The organization itself will be exempt from taxation as long as it does not engage in unrelated business activities. In addition, the tax administration has imposed temporary sanctions if members of an organization practice practices that may improperly exploit any member of the organization (or officers, Directors, etc.) Other than the status of the organization to which the exemption applies. Repealed (the only option available before temporary sanctions are imposed), the IRS can now impose a fine on an organization for engaging in a private sale or private-benefit transaction. [3]

Reliable and nonprofit churches and organizations are special because the first amendment to the U.S. Constitution prevents the government from passing an establishment of religion law, and prohibits "free exercise." [that is, from religion]. It connects only to the United States Federal government, but it was extended to States and local governments in the United States by the 14th amendment at the end of the civil war. Restoring religious freedom, many state laws tend to deal with employment, zoning and the like for churches.

Similarly, some non-profit organizations, such as private organizations, are not subject to anti-discrimination laws that may apply to similar organizations serving the public for profit. For example, American boy scouts do not allow girls, such as calves or boy scouts, and courts believe this does not violate anti-discrimination laws.

Many of the corporate governance issues are similar to non-profit charities with large traders. In principle, the "Agency problem" has problems - the management that manages the charity is different from those from which the charity intends to benefit. In a not-for-profit Corporation, the "Agency problem" is even more complex than in the not-forprofit sector, since charitable beneficiaries do not even report to the management of the non-profit organization. The Board of Directors of most charities is uncertain and new members are elected by a vote of existing members [13, p. 30].

A non-profit organization may be registered in India as a company, Registrar of companies or as a trust through a trust agreement. The third option is to register as part of a -25 company under the companies Act 1956. Regardless of whether a trust, society or company is treated under section 25 , the income tax act gives all categories equal treatment with respect to exemption from their income and the issuance of $80 \mathrm{~g}$ certificates, resulting in donations from donors. nonprofit organization. Foreign contributions to non-profit organizations are governed by $\mathrm{FC}(\mathrm{R})$ a and home office rules.

In the case of an organization that should be known as a charitable organization, it has clarity on income tax in accordance with paragraph 12 of the income tax Act. "Section 2 (15) of the income tax Act defines 'charitable purpose' as 'aid to the poor, education, health care and the promotion of any other General utility'. The purpose of purely religious instruction or worship is not considered a charitable purpose.

Non-profit organizations in India (a) exist independently of the state; (b) are self-controlled by a Board of Trustees or a "steering Committee" / Supervisory Board, which are persons who generally act as fiduciary persons; (c) benefit others, usually outside members of the organization; and (d) they are "non-profit" because they are prohibited from distributing the balance of funds to their members [14, p. 60].

In England and Wales, non-governmental organisations in the form of charities are usually registered with the charity Commission. In Scotland, the leadership of the charity regulator in Scotland performs the same function. Other organizations classified as non-profit organizations in the United States, such as trade unions, are subject to certain rules and are not considered charities in a technical sense. 
[6] Bazarov R.T., Dashina E.I., Funding Problems Non-profit organizations on the example of the Republic of Tatarstan. Basic Research, Economic Sciences. 2015, 2(25), pp. 1725-1729.

Problems faced by NGOs. Capacity-building is an ongoing challenge faced by NGOs for a number of reasons. Most rely on external funding (public funds, charitable Foundation grants, direct donations) to support their activities, and changes in these sources of income can affect the reliability or predictability of the organization. hire and retain staff, maintain facilities, or create programs. In addition, unreliable funding figures, long hours and low wages can create huge turnover rates [15, p. 3115].

Founder's syndrome is an organizational problem related to how they grow. Dynamic founders with a clear vision of project management try to keep the organization under control, even as new employees or volunteers try to expand the scope of the project and try new things.

The most famous NGO in the world today is the bill and Melinda gates Foundation, which has a capital of $\$ 60$ billion (\$27 billion invested were gates and $\$ 30$ billion Warren Buffett).

The second largest capital is the "Howard Hughes Medical Institute", which has a capital of $\$ 14.8$ billion.the Other largest NGO is the British" Wellcome Trust", which is a charitable Foundation. It is worth noting that this estimate did not include universities, at least those with assets in the tens of billions of dollars.

Some NGOs are well known around the world, often for their philanthropy or social focus:

"Amnesty International", a non-profit organization whose main goal is to fight for human rights.

* "Best Business Bureau", an NGO that resolves disputes between consumers and business.

- Oxfam NGO whose main aim is to fight for Ravenstvo and justice throughout the world

* Carnegie Corporation of new York promotes education for all mankind.

* Goodwill Industries, is one of the largest suppliers for those in economic difficulties.

* Red cross and red Crescent organizations whose mission is to protect human life and health.

* UNESCO, which promotes universal respect for justice, law and human rights.

\section{References}

[1] John Yenkey, Managing of Nonprofit Organizations. Fieldstone Alliance. 2016.

[2] Eliott Alvarado, 2016, Nonprofit World, Volume 18 Action Without Borders. Retrieved March 14. 2018

[3] Lester Salmon, The Resilient Sector: Nonprofit America. Brookings Institution Press. 2017

[4] Corporation Centre. Non Profit Retrieved March 14, 2018. 2015.

[5] Stephan Block, Nonprofits Fail: Founder's Syndrome, Fundphobia and Other Obstacles to Success. Jossey- Bass. 2016.

[7] Bazarov R.T., Appalonova N.A., Surkova S.M., Investment Investments in non-profit organizations on the example of the Republic Tatarstan. Fundamental Research. 2016, 8-1, pp. 87-91.

[8] Bazarov R.T., The Role of the Non-Profit Sector in Socio-Economic Economic Development of Russia. Journal of Economics, Law and Sociology. 2011, pp. 17-20.

[9] Bazarov R.T., Improvement of Processes by Non-Profit Organizations. LLC PKK "OMEGA," Kazan. 2013, pp. 153.

[10] Bazarov R.T., To the issue of process improvement Management of Innovation Economy Development in Russia. Economic Analysis: theory and practice. 2014, 4, pp. 55-60.

[11] Bazarov R.T., The Role of the Non-Profit Sector in Socio-Economic Economic Development of Russia. Journal of Economics, Law and Sociology. 2011, pp. 17-20.

[12] Bazarov R.T., Appalonova N.A., Murtazina G.R., Surkova S.M., K Financial support by the State for the activities of non-profit Organizations on the example of the Republic of Tatarstan. Competitiveness in Global World: Economics, Science, Technology, Publishing House: Society with Limited liability "Intelligence-business groups" (Kirov). 2017, 9, 5, pp. 6-11.

[13] R.T. Bazarov, N. A. Appalonova, Faizrakhmanova E., Syurkova S., Evaluation of Non-profit's Approach-es towards Financial Resoyurces Optimi-zation: the Case of Russis. Proceedings of The 19th World Multi-Conference on Systemics, Cybernetics and Informatics, H MSCJ. 2015, pp. 27-32.

[14] R.T. Bazarov, N. A. Appalonova, Faizrakhmanova E., Syurkova S., The Influence of Innovation onto Business Sustainability. Proceedings of The J 9tlt World Multi-Conference on System-ics, Cybernetics and Informatics, H MSCJ. 2015, pp. 57-62.

[15] R.T. Bazarov, N. A. Appalonova, E.I.Basyrova, R.G. Sinetova and T.V. Tishkina, Financial Support by the State Activity of Non-Profit Organizations on the Example of The Russian Federation. Proceedings of The 28 th International Business Information Management Association Conference 9-10 November 2016, Seville, Spain. 2016, pp. 3513-3524.

[16] Michalska M.L.I. Makarska Audit of non-profit organizations. M. Business and service. 2017, 192.

[17] Michalska M.L.I. Makarska non-profit organizations in Russia. Creation. Rights. Tallage. Accounting. Reporting. M.: Business and Service; Publishing the 5th, Rev. and EXT. 2014, 768.

[18] Michalska, M. L. non-profit organizations in Russia. Moscow: Business and service. 2017, 400.

[19] Mitjukova, Elvira Saifullina. Accounting and taxation of noncommercial organizations. M.: Business and service (Dis). 2016, 358.

[20] Filippova N.A. et al. Taxation of non-profit organizations. Moscow: RSUH. 2016, 288

[21] Goncharenko L.I. et al. Taxation of non-profit organizations. Textbook. M.: KnoRus. 2015, 272

[22] Nonprofit organization. Moscow: Alpina Business Books (United Press). $2015,835$.

[23] Petrovskaya, O. V. Foreign non-governmental non-profit and religious organizations in Russia. Moscow: RISI. 2016, 376.

[24] Alexsandr S. Kuznetsov. Russian Professor's meeting. Russian Journal of Physical Education and Sport. 2019, 14(1), pp. 17-22. DOI: 10.14526/2070-4798-2019-14-1-18-24

[25] Peter, F. Drucker Management at a nonprofit. Principles and practice / Peter F. Drucker. Moscow: Williams. 2016, 304 